\title{
Evaluation of melamine and cyanuric acid cytotoxicity: an in vitro study on L929 fibroblasts and CHO cell line
}

\author{
Abdullah MELEKOĞLU ${ }^{1, a}$, Hüsamettin EKİCI ${ }^{2, b, \bowtie}$, Esra ARAT $^{3, c}$, Siyami KARAHAN $^{4, d}$ \\ ${ }^{1}$ Kastamonu University, Department of Genetics and Bioengineering, Kastamonu; ${ }^{2}$ Kırıkkale University, Faculty of Veterinary \\ Medicine, Department of Pharmacology and Toxicology, Kırıkkale; ${ }^{3}$ Kırıkkale University Scientific and Technological Research \\ Application and Research Center, Kırıkkale; ${ }^{4}$ Kırıkkale University, Faculty of Veterinary Medicine, Department of Histology and \\ Embryology, Kirikkale, Turkey.

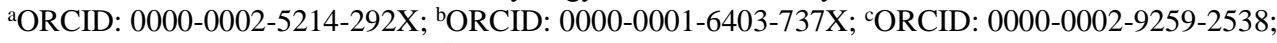
dORCID: 0000-0002-2744-1717

\begin{abstract}
Melamine and its metabolites pose health concern as they are used in various industrial products including feed and drugs. There are a limited number of studies on melamine and cyanuric acid cytotoxicity and cellular damage without a certain conclusion. The present study aimed to evaluate melamine, cyanuric acid and its combined cytotoxic effects using 3-(4.5dimethylthiazol-2-yl) methyl thiazole tetrazolium (MTT) bromide test. The study also evaluated apoptotic and necrotic effect using a double staining method of Hoechst 33342 and propidium iodide. Melamine, cyanuric acid and their combination (1:1) were applied to L929 fibroblasts and Chinese hamster ovary (CHO) cells at various concentrations $(1000 \mu \mathrm{g} / \mathrm{mL}, 500 \mu \mathrm{g} / \mathrm{mL}, 250 \mu \mathrm{g} / \mathrm{mL}, 125 \mu \mathrm{g} / \mathrm{mL}$ and $62.5 \mu \mathrm{g} / \mathrm{mL})$. At the highest concentration $(1000 \mu \mathrm{g} / \mathrm{mL})$, the cell viability dropped down approximately to $50 \%$ both in CHO cells and L929 cells. Melamine, cyanuric acid and their mixture caused cytotoxicity in CHO cells and L929 fibroblasts in dose-dependent manner. Cell death occurred through both apoptosis and mainly necrosis. Both cell types were more sensitive to the mixture of melamine and cyanuric acid and, furthermore, CHO cells were more sensitive than L929 fibroblasts. As a result, melamine, cyanuric acid and their combination caused cytotoxicity in CHO cells and L929 fibroblasts. Further studies should be conducted in different cell lines. These studies should also aim to reveal the mechanism of cytotoxicity and related pathways.
\end{abstract}

Keywords: Apoptosis, cyanuric acid, cytotoxicity, melamine, necrosis.

\section{Melamin ve siyanürik asit sitotoksisitesinin değerlendirilmesi: L929 fibroblast ve CHO hücre hattı üzerine in vitro çalışma}

Özet: Melamin ve metabolitleri yiyecek ve ilaç gibi farklı endüstriyel ürünlerde kullanılması sebebiyle sağlık endişesine neden olmaktadır. Melamin ve siyanürik asit sitotoksisitesi ve bununla ilgili hücre hasarı üzerine çok az sayıda çalışma olup, bu çalışmaların hiçbirisinde de nihai bir sonuca varılamamıştır. Bu çalışmada, 3-(4,5-dimetiltiyazol-2-il) metil tiazol tetrazolium (MTT) bromür testi kullanılarak melamin, siyanürük asit ve bu ikisinin kombinasyonunun sitotoksik etkilerinin değerlendirilmesi amaçlandı. Çalışmada aynı zamanda, Hoechst 33342 ve propidyum iyodürün çift boyama yöntemini kullanarak apoptotik ve nekrotik etkileri de değerlendirdi. Melamin, siyanürik asit ve bunların kombinasyonları (1:1) L929 fibroblastlarına ve CHO hücrelerine çeşitli konsantrasyonlarda (1000 $\mu \mathrm{g} / \mathrm{mL}, 500 \mu \mathrm{g} / \mathrm{mL} 250 \mu \mathrm{g} / \mathrm{mL}, 125 \mu \mathrm{g} / \mathrm{mL}$ and $62,5 \mu \mathrm{g} / \mathrm{mL})$ uygulandı. En yüksek konsantrasyonda $(1000 \mu \mathrm{g} / \mathrm{mL})$, hücre canlılı̆̆ 1 hem CHO hücrelerinde hem de L929 hücrelerinde yaklaşık \%50'ye düştü. Melamin, siyanürik asit ve bunların karışımı, CHO hücrelerinde ve L929 fibroblastlarında doza bağlı sitotoksisiteye neden oldu. Her iki hücre de melamin ve siyanürik asit karışımına daha duyarlı ve ayrıca CHO hücreleri, L929 fibroblastlarına göre daha hassas olarak bulundu. Hücre ölümü, apoptoz ve esas olarak da nekroz yoluyla oluştu. Sonuç olarak, melamin, siyanürik asit ve bunların kombinasyonu CHO hücreleri ve L929 fibroblastlarında sitotoksisiteye neden olmaktadır. Başka hücre hatlarıyla da ilave çalışmaları yapılmalıdır. Bu bu çalışmalar sitotoksisitenin mekanizması ve ilgili hücre yolaklarının aydınlanmasını amaçlamalıdır.

Anahtar sözcükler: Apoptoz, siyanürik asit, sitotoksisite, melamin, nekroz.

\section{Introduction}

Melamine (2.4.6-triamino-1.3.5-triazine, C3H6N6) is a synthetic chemical used in various fields of industry for production materials including plastics, adhesives, fertilizers, housewares, and others $(29,34,37)$. As a sanitizing agent, melamine is also used in food processing 
equipment and instruments (11, 33, 37). Melamine was also investigated for its anticancer potential activity, but the related results resulted in a lack of efficacy $(18,37)$. Besides these useful potentials, melamine toxicity is one of the major concerns, especially in the food industry. Acute melamine toxicity is generally considered to be low in animals and frequently targets kidney $(5,20)$. However, a number of recent studies concluded that pathologies resulting from melamine-related toxicity are not limited to renal tissues $(15,36)$. It was recorded that chronic exposure to melamine may cause reproductive damage to the eye, skin and respiratory system $(28,42)$. As a consequence of melamine ingestions especially at higher doses, melamine causes testicular toxicity in mice with a significant rate of sperm abnormality and DNA damage $(36,38,43)$.

Cyanuric acid (1.3.5-triazine-2.4.6-triol; CAS No. 108-80-5) is a structurally related constituent to melamine and frequently used in a ruminant diet as a feed additive and chlorine-stabilizing agent $(11,19,21)$. As a structural analogue of melamine, cyanuric acid alone exhibits rather low acute toxicity $(22,24)$. Cyanuric acid has a strong mutual affinity to melamine and it has been reported that the melamine and cyanuric acid mixture or its combined effect was held responsible for the renal injury $(22,26)$. In the presence of cyanuric acid, melamine forms hydrogen bonds with cyanuric acid that results in the formation of an insoluble crystal named melamine cyanurate (10). A number of recent research concluded that melamine with or without cyanuric acid seems to be toxic to tissues and organ systems including testis, spermatozoid $(6,36,43)$, liver, stomach, small intestine $(7,36)$ and hippocampus $(1$, 2). In a previous study by Yin et al. (37) concluded that ingestion of melamine alone or its combination with cyanuric acid had certain toxic effects on mouse spleen (39). A recent rat study concluded that melamine passes through the placenta in a dose-dependent manner $(9,17)$. Thus, melamine toxicity pose treats to unborn babies as they are more sensitive to chemical insults (3). Both melamine and cyanuric acid even at low-doses can interfere with the blood-testis barrier in mouse (6). An et al. (1) reported that the melamine toxicity in the nervous system is selective for the hippocampus in which melamine can induce the free radical formation and lipid peroxidation. Another study by An and Zhang (2) investigated prenatal exposure to melamine that resulted in impaired synaptic activity in the hippocampus (38).

Although limited in number, in vitro studies have also revealed melamine cytotoxicity using various cell lines, e.g. differentiated PC12 cells and mouse spleen lymphocytes (14, 37). Partanen et al. (23) observed decreased cell viability of trophoblast derived BeWo cells in response to melamine exposure with or without the presence of cyanuric acid. Cell lines vary in response or sensitivity to melamine and cyanuric acid exposure. For instance, Choi et al. (8) reported that $\mathrm{CHN}$ human renal adenocarcinoma cell line was more sensitive to melamine, cyanuric acid or their combination compared to MDCK canine kidney epithelial cell line. In a study by Radko et al. (25), hepatoma (line $\mathrm{FaO}$ ) seems to be more sensitive than rat skeletal muscle (line L6) to melamine. Thus, there is a growing interest in characterizing cytotoxicity of melamine, cyanuric acid or their mixture on different cell lines.

The mechanism of melamine and cyanuric acid cytotoxicity or activity has also been one of the major scientific interests. Melamine alone or its combination with cyanuric acid resulted in liver damage in mice in a dose-dependent manner. The damaged liver areas were characterized by apoptosis in hepatocytes with up regulation of apoptosis-related genes, Bax, cyt-c and caspase-3 (7, 35, 36, 40). Yiu et al. (41) reported that melamine induced apoptosis in the porcine renal proximal tubule cell line, LLC-PK1, through Ca2-sensing receptor activation. Another study by Gohel et al. (12) found that melamine cyanurate damaged the integrity of tight junction when crystals were physically formed on the apical cell surface. It also causes oxidative DNA damage, in addition to up-regulation of inflammatory cytokines including IL-5, IL-6, IL-8, and MCP-1. Thus, there is a growing scientific interest to reveal the degree of cell viability in different cells and the mechanism of cell death as a consequence of exposure to melamine with the presence or absence of cyanuric acid.

In the present study, we aimed to investigate cytotoxic, apoptotic and necrotic effects of melamine and cyanuric acid and their combination on well characterized two cell lines, mouse L929 fibroblasts and CHO cells, an epithelial cell line derived from the Chinese hamster ovary.

\section{Material and Methods}

Determination of cytotoxicity using MTT test: MTT is a very sensitive test to determine cell proliferation and cell viability using 3.[4.5-dimethylthiazol-2-yl]-2.5diphenyltetrazolium bromide (MTT) salt. L929 fibroblasts and Chinese hamster ovary (CHO) cells were inoculated into 96 well plates at a concentration of $10 \times 10^{3}$ per well. Cells were incubated for 24 hours in an incubator conditioned with $5 \% \mathrm{CO}_{2}$ at $37{ }^{\circ} \mathrm{C}$. First, $10 \mathrm{mg}$ of melamine and cyanuric acid were poured into separate tubes and $1 \mathrm{ml}$ of $10 \%$ DMSO was added and sonicated afterwards. Then, $9 \mathrm{ml}$ of DMEM medium was also added to each tube and vortexed. Then, melamine (99\%, SigmaAldrich, USA), cyanuric acid (98\%, Sigma-Aldrich, USA) and their combination (1:1) were applied to L929 fibroblasts and $\mathrm{CHO}$ cells at various concentrations $(1000 \mu \mathrm{g} / \mathrm{mL}, 5090 \mu \mathrm{g} / \mathrm{mL}, 250 \mu \mathrm{g} / \mathrm{mL}, 125 \mu \mathrm{g} / \mathrm{mL}$ and 
$62.5 \mu \mathrm{g} / \mathrm{mL}$ ) and incubated for 24 hours. Samples were studied in triplicate. For control, only cell medium was used. At the end of 24 hours, cell medium was removed from the wells and $50 \mu \mathrm{L}$ MTT solution was added to each well. Cells were incubated with MTT solution for 2 hours. Upon draining the MTT solution, $100 \mu \mathrm{l}$ of isopropanol was added into each cells. Then, it was shaken gently and read in an ELISA plate reader at $570 \mathrm{~nm}$ wavelength. The final data of cell viability (\%) were obtained by comparing the results obtained from the ELISA reader to that of control.

Determination of apoptosis and necrosis using double staining method: The double staining cocktail was prepared as follows: Ribonuclease-A stock solution was prepared as it contained $10 \mathrm{mg}$ of RNase in $1 \mathrm{ml}$ PBS. The Hoechst 33342 and PI stock solutions were prepared as it contained $200 \mu \mathrm{g}$ of Hoechst 33342 and $100 \mu \mathrm{g}$ of PI in1 $\mathrm{ml}$ of PBS. The working solution was prepared as follows: $100 \mu \mathrm{L}$ of RNAse and $500 \mu \mathrm{L}$ Hoechst, and $100 \mu \mathrm{L}$ of PI stock solutions were added into $10 \mathrm{~mL}$ PBS.

L929 fibroblasts and CHO cells were inoculated into 48 well plates at a concentration of $10 \times 10^{3}$ per well. Cells were incubated for 24 hours in an incubator conditioned with $5 \% \mathrm{CO}_{2}$ at $37^{\circ} \mathrm{C}$. Then, melamine, cyanuric acid and their combination (1:1) were applied to L929 fibroblasts and $\mathrm{CHO}$ cells at various concentrations $(1000 \mu \mathrm{g} / \mathrm{mL}, 500$ $\mu \mathrm{g} / \mathrm{mL}, 250 \mu \mathrm{g} / \mathrm{mL}, 125 \mu \mathrm{g} / \mathrm{mL}$ and $62.5 \mu \mathrm{g} / \mathrm{mL})$ and incubated for 24 hours. Samples were studied in triplicate. For control, only cell medium was used. At the end of 24 hours, cell medium was removed from the wells and 79 $\mu \mathrm{L}$ of the working double staining solution was added to each well. The 48 well plates were incubated in an incubator for $15 \mathrm{~min}$. For this $15 \mathrm{~min}$ incubation period, a completely dark environment is required. At the end of incubation, cells were evaluated in a fluorescence microscope. Apoptotic and necrotic cells were visualized using the DAPI and FITC (480-520nm wavelength) fluorescence filters, respectively.

Statistical analysis: For statistical analyses, the presence of difference was examined using the one way analysis of variance (ANOVA). In case of presence of a significant difference, the Tukey test was conducted for multiple comparisons. For comparison between $\mathrm{CHO}$ cell and L929 fibroblast for the same dose of the same chemicals, the student's $t$-test was used. Data were expressed as mean \pm standard deviation. A $P$ value of $<0.05$ was considered statistically significant.

\section{Results}

MTT test: Based on ELISA plate reader, the cell viability (\%) results on $\mathrm{L} 929$ fibroblasts and $\mathrm{CHO}$ cells were given in Table 1. The cell viability in L929 fibroblasts and CHO cells after application of melamine, cyanuric acid, and their mixture decreased remarkably in a dose dependent manner. The cell viability on L929 fibroblasts was the lowest at the highest dose used (1000 $\mu \mathrm{g} / \mathrm{mL}$ ) without any significance to any group ( $\mathrm{P}>0.05)$. The cell viability rates on L929 fibroblasts after application of melamine, cyanuric acid and their mixture at a dose of $1000 \mu \mathrm{g} / \mathrm{mL}$ were $49.40 \pm 1,14 \%, 51.20 \pm 1.30$, and $47.80 \pm 1.30 \%$ respectively. Beginning at the dose of $1000 \mu \mathrm{g} / \mathrm{mL}$, the cell viability was significantly lower in L929 fibroblasts treated with mixture of melamine and cyanuric acid compared to those treated either with melamine or cyanuric acid alone $(\mathrm{P}<0.05)$. For instance, the cell viability rates on L929 fibroblasts following application of melamine, cyanuric acid and their mixture at a dose of $62.5 \mu \mathrm{g} / \mathrm{mL}$, were $100.60 \pm 1.14 \%, 98.20 \pm 1.30$ $\%$, and $78.20 \pm 0.83$ respectively $(\mathrm{P}<0.05)$.

Table 1. Cell viability (\%) of CHO cells and L929 fibroblasts upon exposure to melamine, cyanuric acid and their mix (1:1)

\begin{tabular}{llccc}
\hline $\begin{array}{l}\text { Concentration } \\
(\boldsymbol{\mu} \mathrm{g} / \mathrm{mL})\end{array}$ & & Melamine & Cyanuric acid & Melamine-Cyanuric acid \\
\hline $1000 \mu \mathrm{g} / \mathrm{mL}$ & CHO cells & $48.40 \pm 0.54^{\mathrm{a} *}$ & $48.20 \pm 1.30^{\mathrm{a}}$ & $41.20 \pm 0.83^{\mathrm{b}}$ \\
& L929 Fibroblasts & $49.40 \pm 1.14^{\mathrm{ab}}$ & $51.20 \pm 1.30^{\mathrm{a}}$ & $47.80 \pm 1.30^{\mathrm{b}}$ \\
$500 \mu \mathrm{g} / \mathrm{mL}$ & CHO cells & $64.60 \pm 1.14^{\mathrm{b} *}$ & $84.60 \pm 1.14^{\mathrm{a} *}$ & $54.60 \pm 1.14^{\mathrm{c} *}$ \\
& L929 Fibroblasts & $79.20 \pm 1.64^{\mathrm{a}}$ & $80.20 \pm 1.78^{\mathrm{a}}$ & $51.40 \pm 1.34^{\mathrm{b}}$ \\
$250 \mu \mathrm{g} / \mathrm{mL}$ & CHO cells & $77.60 \pm 1.14^{\mathrm{b} *}$ & $86.40 \pm 1.51^{\mathrm{a} *}$ & $56.80 \pm 0.83^{\mathrm{c} *}$ \\
& L929 Fibroblasts & $96.20 \pm 3.0^{\mathrm{a}}$ & $95.60 \pm 5.1^{\mathrm{a}}$ & $52.60 \pm 2.7^{\mathrm{b}}$ \\
$125 \mu \mathrm{g} / \mathrm{mL}$ & CHO cells & $82.40 \pm 1.14^{\mathrm{a} *}$ & $91.20 \pm 1.30^{\mathrm{a} *}$ & $68.60 \pm 1.14^{\mathrm{b} *}$ \\
& L929 Fibroblasts & $97.80 \pm 0.83^{\mathrm{b}}$ & $95.80 \pm 1.09^{\mathrm{a}}$ & $62.80 \pm 1.30^{\mathrm{c}}$ \\
$62.5 \mu \mathrm{g} / \mathrm{mL}$ & CHO cells & $85.80 \pm 0.83^{\mathrm{a} *}$ & $92.80 \pm 1.30^{\mathrm{a} *}$ & $69.80 \pm 0.83^{\mathrm{b} *}$ \\
& L929 Fibroblasts & $100.60 \pm 1.14^{\mathrm{b}}$ & $98.20 \pm 1.30^{\mathrm{a}}$ & $78.20 \pm 0.83^{\mathrm{c}}$ \\
\hline
\end{tabular}

Note: Data with different letters in superscript in the same row is statistically significant $(\mathrm{P}<0.05)$. Presence of an asterisk $(*)$ indicates a significant difference in the same column for the same dose $(\mathrm{P}<0.05)$ 
The cell viability on $\mathrm{CHO}$ cell was the lowest at the highest dose used $(1000 \mu \mathrm{g} / \mathrm{mL})$ and it was lower in cells treated with the mixture of melamine and cyanuric acid $(\mathrm{P}>0.05)$. The cell viability rates on $\mathrm{CHO}$ cell after application of melamine, cyanuric acid and their mixture at a dose of $1000 \mu \mathrm{g} / \mathrm{mL}$ were $48.40 \pm 0.54,48.20 \pm 1.30$, and $41.20 \pm 0.83 \%$ respectively. In MTT cells, the order of cytotoxicity induction in $\mathrm{CHO}$ cells from highest to lowest was as follows: the mixture > melamine > cyanuric acid. Such a distinction was the most prominent especially at a dose of $500 \mu \mathrm{g} / \mathrm{mL}$ and $250 \mu \mathrm{g} / \mathrm{mL}(\mathrm{P}<0.05)$ although the cell viability was always lower in $\mathrm{CHO}$ cells exposed to the mixture $(\mathrm{P}<0.05)$.

Table 1 also compares the difference between $\mathrm{CHO}$ cells and L929 fibroblasts for the cell viability following exposure to various concentrations of melamine, cyanuric acid and their mixture. $\mathrm{CHO}$ cells seem to be more sensitive to all. The difference was significant at all concentrations of melamine, cyanuric acid and the mixture $(\mathrm{P}<0.05)$, except at the highest concentrations of cyanuric acid and the mixture.

Apoptotic and necrotic index: Apoptotic cells were determined under a fluorescence microscope using the
DAPI filter. The apoptotic cell nuclei were identified as they illuminate bright shining blue color (Figures 1 and 2). Apoptotic rates in $\mathrm{L} 929$ fibroblasts and $\mathrm{CHO}$ cells exposed to melamine, cyanuric acid and their mixture were given in Tables 2. The apoptotic index in both $\mathrm{CHO}$ cells and L929 fibroblasts is limited and there was no significant difference in comparison of cytotoxicity either of substances, except at $500 \mu \mathrm{g} / \mathrm{mL}$ and $125 \mu \mathrm{g} / \mathrm{mL}$ concentrations of melamine applied on to $\mathrm{CHO}$ cells. In comparison between $\mathrm{CHO}$ cells and $\mathrm{L} 929$ fibroblasts, the significant difference occurred at $125 \mu \mathrm{g} / \mathrm{mL}$ of cyanuric acid and the mixture. The necrotic index in both kinds of cells increased in a dose dependent manner (Table 3). The mixture of melamine and cyanuric acid mixture caused the highest necrotic effects, specifically at $500 \mu \mathrm{g} / \mathrm{mL}, 250$ $\mu \mathrm{g} / \mathrm{mL}$ and $125 \mu \mathrm{g} / \mathrm{mL} \quad(\mathrm{P}<0.05)$. There was no statistically significant difference between $\mathrm{CHO}$ cells and L929 fibroblasts by means of the necrotic rate following exposure to any substances used $(\mathrm{P}>0.05)$. The double staining of L929 cells and CHO cells were depicted in photomicrographs in Figures 1 and 2, respectively.

Table 2. The apoptotic index (\%) resulting from exposure of CHO cells and L929 fibroblasts upon exposure to melamine, cyanuric acid and their mix (1:1)

\begin{tabular}{clccc}
\hline \multicolumn{1}{c}{ Concentration } & & Melamine & Cyanuric acid & Melamine-Cyanuric acid \\
\hline $1000 \mu \mathrm{g} / \mathrm{mL}$ & CHO cells & $5 \pm 1.58$ & $5.8 \pm 1.92$ & $8 \pm 2.54$ \\
& L929 Fibroblasts & $6.6 \pm 1.51$ & $5.2 \pm 1.09$ & $7 \pm 2.54$ \\
$500 \mu \mathrm{g} / \mathrm{mL}$ & CHO cells & $4 \pm 0.70^{\mathrm{a}}$ & $4.6 \pm 1.14^{\mathrm{a}}$ & $7 \pm 2.23^{\mathrm{b}}$ \\
& L929 Fibroblasts & $5.4 \pm 1.14$ & $5.8 \pm 1.48$ & $6.4 \pm 2.07$ \\
$250 \mu \mathrm{g} / \mathrm{mL}$ & CHO cells & $3.2 \pm 0.83$ & $4 \pm 0.70$ & $4.6 \pm 1.14$ \\
& L929 Fibroblasts & $4.4 \pm 1.34$ & $3.4 \pm 1.14$ & $4.4 \pm 0.89$ \\
$125 \mu \mathrm{g} / \mathrm{mL}$ & CHO cells & $2.4 \pm 0.54^{\mathrm{a}}$ & $4.6 \pm 0.89^{\mathrm{b}}$ & $3.8 \pm 0.83^{\mathrm{b}}$ \\
& L929 Fibroblasts & $2.6 \pm 0.89$ & $2 \pm 1.41^{*}$ & $2.2 \pm 0.83^{*}$ \\
$62.5 \mu \mathrm{g} / \mathrm{mL}$ & CHO cells & $1.6 \pm 0.89$ & $2 \pm 0.70$ & $3 \pm 1.00$ \\
& L929 Fibroblasts & $1.6 \pm 0.54$ & $1.6 \pm 0.89$ & $2.6 \pm 0.54$ \\
\hline
\end{tabular}

Note: Data with different letters in superscript in the same row is statistically significant $(\mathrm{P}<0.05)$. Presence of an asterisk $(*)$ indicates a significant difference in the same column for the same dose $(\mathrm{P}<0.05)$

Table 3. Necrotic index (\%) in CHO cells and L929 fibroblasts upon exposure to melamine, cyanuric acid and their mix (1:1).

\begin{tabular}{clccc}
\hline Concentration & & Cyanuric acid & Melamine & Melamine-Cyanuric acid \\
\hline $1000 \mu \mathrm{g} / \mathrm{mL}$ & CHO cells & $33 \pm 4.94$ & $36.4 \pm 3.64$ & $40.2 \pm 4.81$ \\
& L929 Fibroblasts & $38 \pm 2.86$ & $34 \pm 4.12$ & $37 \pm 4.35$ \\
$500 \mu \mathrm{g} / \mathrm{mL}$ & CHO cells & $18.8 \pm 5.76^{\mathrm{a}}$ & $24.8 \pm 7.66^{\mathrm{ab}}$ & $33 \pm 4.30^{\mathrm{b}}$ \\
& L929 Fibroblasts & $16.4 \pm 3.64^{\mathrm{a}}$ & $19.80 \pm 5.71^{\mathrm{a}}$ & $28.8 \pm 4.65^{\mathrm{b}}$ \\
$250 \mu \mathrm{g} / \mathrm{mL}$ & CHO cells & $14.8 \pm 3.19^{\mathrm{a}}$ & $16.8 \pm 5.16^{\mathrm{a}}$ & $28.4 \pm 4.77^{\mathrm{b}}$ \\
& L929 Fibroblasts & $12 \pm 2.73^{\mathrm{a}}$ & $13.6 \pm 7.19^{\mathrm{a}}$ & $25 \pm 5.09^{\mathrm{b}}$ \\
$125 \mu \mathrm{g} / \mathrm{mL}$ & CHO cells & $7.2 \pm 3.96^{\mathrm{a}}$ & $7.6 \pm 2.40^{\mathrm{a}}$ & $14 \pm 3.39^{\mathrm{b}}$ \\
& L929 Fibroblasts & $7 \pm 4.18^{\mathrm{a}}$ & $6.4 \pm 2.07^{\mathrm{a}}$ & $14.2 \pm 4.43^{\mathrm{b}}$ \\
$62.5 \mu \mathrm{g} / \mathrm{mL}$ & CHO cells & $4.4 \pm 2.07$ & $5.2 \pm 1.92$ & $7.4 \pm 2.07$ \\
& L929 Fibroblasts & $4.2 \pm 1.48$ & $4.8 \pm 1.64$ & $5.6 \pm 1.94$ \\
\hline
\end{tabular}

Note: Data with different letters in superscript in the same row is statistically significant $(\mathrm{P}<0.05)$. There were significant differences between CHO cells and L929 fibroblasts for any substance used. 


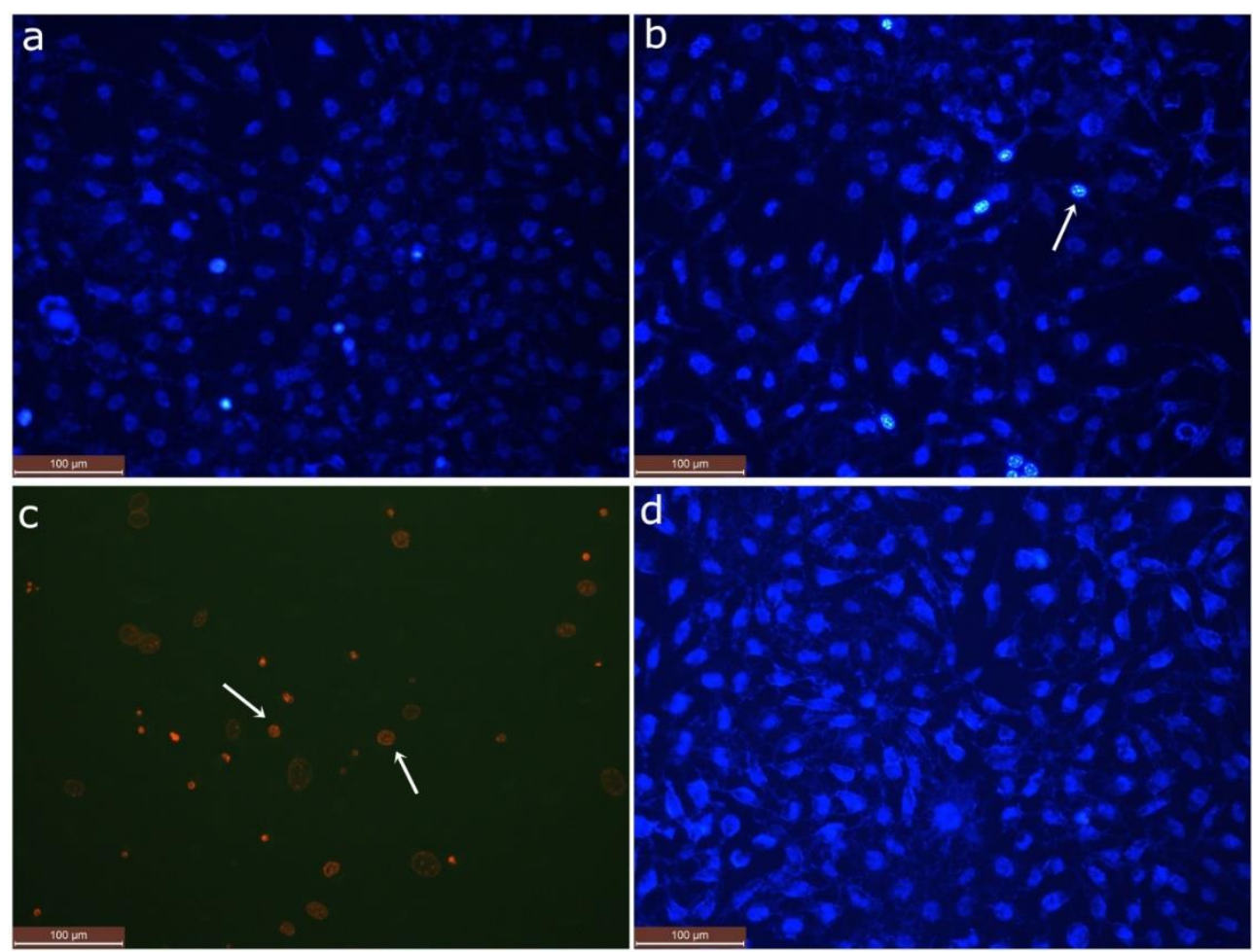

Figure 1. Apoptosis and necrosis in L929 fibroblasts. a) Apoptotic figures following exposure to cyanuric acid at a concentration of $250 \mu \mathrm{g} / \mathrm{mL}$. b) Apoptotic figures (arrows) following exposure to melamine at a concentration of $125 \mu \mathrm{g} / \mathrm{mL}$. c) Necrotic figures (arrows) following exposure to the mixture of melamine and cyanuric acid at a concentration of $125 \mu \mathrm{g} / \mathrm{mL}$. d) Absence of apoptotic figures in untreated cells.

In fluorescence microscopy, the DAPI filter was used to observe Hoechst 33342 staining in a, b, and d while the FITC filter was used to observe propidium iodide staining in $\mathrm{c}$.

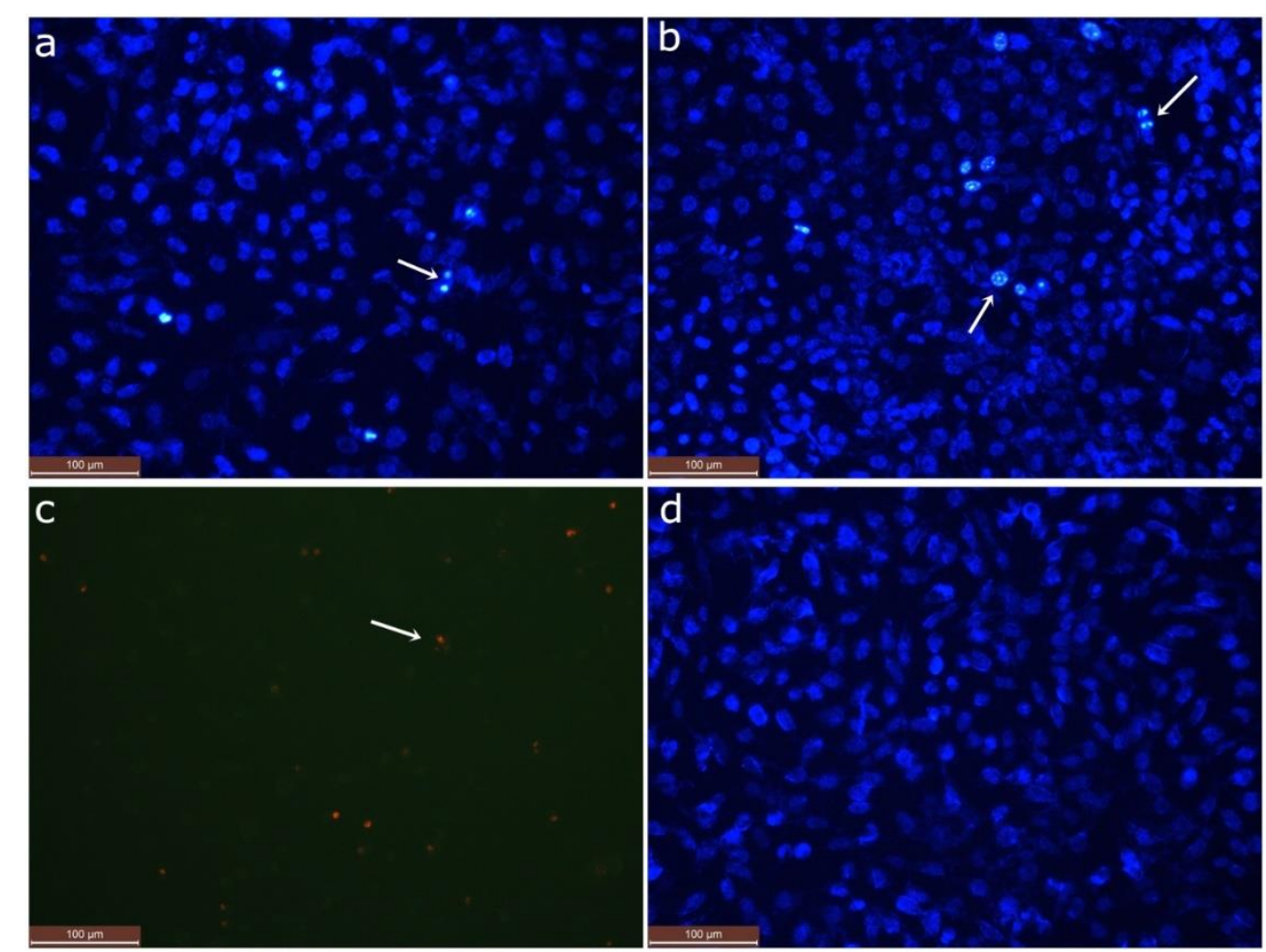

Figure 2. Apoptosis and necrosis in $\mathrm{CHO}$ cells. a) Apoptotic figures following exposure to cyanuric acid at a concentration of 250 $\mu \mathrm{g} / \mathrm{mL}$. b) Apoptotic figures (arrows) following exposure to melamine at a concentration of $125 \mu \mathrm{g} / \mathrm{mL}$. c) Necrotic figures (arrows) following exposure to the mixture of melamine and cyanuric acid at a concentration of $125 \mu \mathrm{g} / \mathrm{mL}$. d) Absence of apoptotic figures in untreated cells.

In fluorescence microscopy, the DAPI filter was used to observe Hoechst 33342 staining in $a, b$, and d while the FITC filter was used to observe propidium iodide staining in $\mathrm{c}$. 


\section{Discussion and Conclusion}

Living organisms are exposed to so many different natural or synthetic materials in various ways such as skin exposure, oral ingestion. In this regard, it is so important to characterize these substances for their biological activities as well as potential toxicities with regard to their chemical nature. In vitro cytotoxicity is the first step to reveal the presence or absence of a direct toxic effect at the cellular level. It is also used to illuminate the mechanism of cell death and related pathways. There are various cytotoxicity test including MTT, XTT, neutral red, agar diffusion, and lactate dehydrogenase. In the present study, we preferred MTT test to assess cytotoxicity on L929 fibroblasts and $\mathrm{CHO}$ resulting from exposure to melamine, cyanuric acid, and their combination. The MTT test is a colorimetric test and widely used to evaluate cell viability. The MTT test is also called the succinate dehydrogenase activity test because the enzymatic reduction of MTT to MTT-formazan is catalyzed by mitochondrial succinate dehydrogenase in live cells. The cytotoxicity data obtained from the MTT test was supported by the apoptotic and necrotic index data to analyze the pattern of cell death. A double staining method of Hoechst (33342) and propidium iodide (PI) is frequently used to reveal apoptosis and necrosis in cell culture (32). The prominent difference between apoptotic and necrotic cell nuclei is that DNA becomes condensed during apoptosis, but such a condensation process does not occur during necrosis. Nuclear condensation can be revealed by dyes such as Hoechst 33342 those effluxes across the cell membrane and binds to DNA. Unlike Hoechst (33342), PI does not pass across the intact cell membrane. Thus, PI stains DNA and RNA in cells with impaired cell membrane integrity and reveal secondary necrosis. In the present study, we depicted the presence of cell death not only through apoptotic by also necrotic path due to cytotoxicity induced with either melamine, or cyanuric acid or their combinations.

In vitro studies are very important to determine the cytotoxic potential of the substances. Sun et al. (30) concluded that melamine caused cytotoxicity in vitro on the rat NRK-52E and human 293T kidney cells with IC $_{50}$ values of $1.89 \mathrm{mg} / \mathrm{mL}$ and $2.07 \mathrm{mg} / \mathrm{mL}$, respectively. In Radko et al. (25) study melamine exerted cytotoxicity on the rat $\mathrm{FaO}$ hepatoma cells and the rat skeletal $\mathrm{L} 6$ cells after 48 hours of exposure with $\mathrm{EC}_{50}$ values of $6.4 \pm 0.62$ $\mathrm{mM}$, and $8.2 \pm 1.51 \mathrm{mM}$, respectively. In the present study, melamine and cyanuric acid caused cytotoxicity in $\mathrm{CHO}$ and L929 fibroblasts in a dose-dependent manner. Almost fifty percent of cells died at a concentration of $1000 \mu \mathrm{g} / \mathrm{ml}$ following the application of melamine or cyanuric acid alone. Through a rat study as well as an in vitro study on the rat NRK-52E and human 293T kidney cells, Sun et al. (30) also concluded that melamine is more toxic than cyanuric acid. A similar conclusion was made by Choi et al. (8) on ACHN human renal adenocarcinoma cell line and the MDCK canine kidney epithelial cell line.

Although melamine toxicity with the presence or absence of cyanuric acid has been one of public interest, the number of related studies is limited. Some in vitro cytotoxicity studies have been conducted. As it has been considered that the kidney is the major target organ in melamine and cyanuric acid, the kidney epithelial cells such as NRK-52E and 293T cell lines were studied in vitro $(16,30,41)$. It has been revealed that the kidney is not the only target organ for melamine toxicity (37). Thus, some other cell lines including rat hepatoma cells, rat skeletal cells (25), colon adenocarcinoma cells (31), and spleen lymphocytes (37) were investigated for melamine cytotoxicity. In this study, we used two different wellcharacterized cell lines, $\mathrm{CHO}$ and L929. The CHO cell is of epithelial origin and derived from Chinese hamster Ovary (4) while L929 fibroblast is of mouse origin and routinely used in cytotoxicity studies (27). In the present study, $\mathrm{CHO}$ cells seem to be more sensitive to melamine with or without cyanuric acid. This difference was often significant in melamine exposed to cells. Such a difference should be further investigated by means of recovery potentials and internal pathways of cells including repair mechanism, scavenging system. The difference in cytotoxicity profile has also been reported by Choi et al. (8) on ACHN human renal adenocarcinoma cells and MDCK canine kidney epithelial cell lines. They found ACHN human renal adenocarcinoma cells were sensitive to melamine, cyanuric acid and their combination than MDCK canine kidney epithelial cell lines. In support of the previous studies, the present study found that melamine seems to be more toxic than cyanuric acid, which is more prominent in CHO cells. Furthermore, both CHO cells and L929 fibroblasts were more sensitive to the mixture of melamine and cyanuric acid than melamine or cyanuric acid alone. This finding was also reported in previous studies. Yin et al. (37) reported that the administration of the mixture of melamine and cyanuric acid caused a declining tendency in the stimulation index of spleen lymphocyte. In another study by Sun et al. (30) concluded that melamine and cyanuric acid results in the formation of a melamine cyanuric acid complex, the toxicity of which is greater than the toxicity of melamine or cyanuric acid alone. In an animal study, Choi et al. (8) observed the absence of adverse effects in renal function in rats treated either with melamine alone or cyanuric acid alone while but nephrotoxicity related findings were present in rats with the mixture of melamine and cyanuric acid.

There have been some studies related to the mechanism of melamine cytotoxicity. Yiu et al. (41) 
proposed a mechanism of melamine cytotoxicity in the renal epithelial cell line, LLC-PK1i in which melamine activates $\mathrm{Ca} 2$-sensing receptors, which in turn causes a sustained $\mathrm{Ca} 2$ entry in the renal epithelial cell line, LLCPK1. Activation of Ca2-sensing receptors also causes a rise in $[\mathrm{Ca} 2]_{i}$ that results in increased ROS production. Elevated $[\mathrm{Ca} 2]_{\mathrm{i}}$ and ROS production cause an increase in apoptotic and necrotic cell death. Yin et al. (37) reported that cell death in spleen lymphocytes as a consequence of exposure to melamine with or without cyanuric acid occurs through an early apoptotic pathway or late apoptotic/necrotic pathways. Guo et al. (13) concluded that melamine increased apoptotic and necrotic rates in the NRK-52e cells in a dose-dependent manner and melamine causes apoptosis in the NRK-52e cells resulting from excessive intracellular ROS production and the activation of p38 MAPK pathway. Han et al. (14) concluded that melamine causes cytotoxicity in differentiated PC12 Cells through apoptosis rather than necrosis. This finding is contradictory to the present study that found cell death due to exposure to melamine, cyanuric acid or their mixture occurs mainly through necrosis. The present study found that cell death thorough apoptosis in CHO cells and L929 fibroblasts following exposure to melamine, cyanuric acid or their mixture is limited. However, the necrotic cell death seems more prominent for both cells. This controversy should be further investigated through other methods and assays.

In conclusion; melamine, cyanuric acid and their mixture cause cytotoxicity in CHO cells and L929 fibroblasts in dose dependent manner. Cell death occurred through both apoptosis and mainly necrosis. Both cell types were more sensitive to the mixture of melamine and cyanuric acid compared to their use alone. When compared to the cells used, $\mathrm{CHO}$ cells were more sensitive than L929 fibroblasts to melamine, cyanuric acid and their mixture. As a result, melamine, cyanuric acid and their combination cause cytotoxicity in CHO cells and L929 fibroblasts. Further studies should be conducted in different cell lines. These studies should also aim to reveal the mechanism of cytotoxicity and related pathways.

\section{Financial Support}

This research received no grant from any funding agency/sector.

\section{Ethical Statement}

This study does not present any ethical concerns.

\section{Conflict of Interest}

The authors declared that there is no conflict of interest.

\section{References}

1. An L, Li Z, Yang Z, et al (2012): Melamine induced cognitive impairment associated with oxidative damage in rat's hippocampus. Pharmacol Biochem Behav, 102, 196202.

2. An L, Zhang T (2014): Prenatal melamine exposure induces impairments of spatial cognition and hippocampal synaptic plasticity in male adolescent rats. Reprod Toxicol, 49, 78-85.

3. Anderson LM, Diwan BA, Fear NT, et al (2000): Critical windows of exposure for children's health: cancer in human epidemiological studies and neoplasms in experimental animal models. Environ Health Perspect, 108, 573-594.

4. Batsalova T, Kolchakova D, Dzhambazov B (2018): In vitro cytotoxicity of cyanuric acid and selected derivatives. Toxicol Forensic Med Open J, 3, 14-21.

5. Brown CA, Jeong KS, Poppenga RH, et al (2007): Outbreaks of renal failure associated with melamine and cyanuric acid in dogs and cats in 2004 and 2007. J Vet Diagn Invest, 19, 525-531.

6. Chang, L., She R, Ma L, et al (2014): Acute testicular toxicity induced by melamine alone or a mixture of melamine and cyanuric acid in mice. Reprod Toxicol, 46, 1-11.

7. Chang L, Yue Z, She R, et al (2015): The toxic effect of a mixture of melamine and cyanuric acid on the gastrointestinal tract and liver in mice. Res Vet Sci, 102, 234-237.

8. Choi L, Kwak MY, Kwak EH, et al (2010): Comparative nephrotoxicity induced by melamine, cyanuric acid, or a mixture of both chemicals in either Sprague-Dawley rats or renal cell lines. J Toxicol Environ Health A, 73, 1407-1419.

9. Chu CY, Chu KO, Chan JY, et al. (2010): Distribution of melamine in rat foetuses and neonates. Toxicol Lett, 199, 398-402.

10. Field A, Field J (2010): Melamine and cyanuric acid do not interfere with Bradford and ninhydrin assays for protein determination. Food Chem, 121, 912-917.

11. Filazi A, Sireli UT, Ekici H, et al (2012): Determination of melamine in milk and dairy products by high performance liquid chromatography. J Dairy Sci, 95, 602-608.

12. Gohel MDI, Yuen JWM, Chi-Fai Ng (2018): Cytokine and inflammatory-related gene expression of melamine cyanurate on human renal proximal tubular cells. Clin Res Open Access, 4, 1-7.

13. Guo C, Yuan H, He Z (2012): Melamine causes apoptosis of rat kidney epithelial cell line (NRK-52e cells) via excessive intracellular ROS (reactive oxygen species) and the activation of p38 MAPK pathway. Cell Biol Int, 36, 383-389.

14. Han YG, Liu SC, Zhang T, et al (2011): Induction of apoptosis by melamine in differentiated PC12 cells. Cell Mol Neurobiol, 31, 65-71.

15. Hau AK, Kwan TH, Li PK (2009): Melamine toxicity and the kidney. J Am Soc Nephrol, 20, 245-250.

16. Hsieh TJ, Hsieh PC, Tsai YH, et al (2012): Melamine induces human renal proximal tubular cell injury via transforming growth factor- $\beta$ and oxidative stress. Toxicol Sci, 130, 17-32.

17. Jingbin W, Ndong M, Kai H, et al (2010): Placental transfer of melamine and its effects on rat dams and fetuses. Food Chem Toxicol, 48, 1791-1795. 
18. Langman CB, Alon U, Ingelfinger J, et al (2009): $A$ position statement on kidney disease from powdered infant formulabased melamine exposure in Chinese infants. Pediatr Nephrol, 24, 1263-1266.

19. Lee IC, Ko JW, Park S, et al (2016): Melamine and cyanuric acid co-exposure causes renal dysfunction and structural damage via MAPKs and mitochondrial signaling. Food Chem Toxicol, 96, 254-262.

20. Melnick RL, Boormanm GA, Haseman JK, et al (1984): Urolithiasis and bladder carcinogenicity of melamine in rodents. Toxicol Appl Pharm, 72, 292-303.

21. Organization for Economic Cooperation and Development (1999): Screening Information Data Set for Isocyanuric Acid. CAS No. 108-80-5. Available at http://www.chem.unep.ch/irptc/sids/OECDSIDS/108805.p df. (Accessed December 02, 2019).

22. Pang J, Li GQ, Li CR, et al (2013): Toxicokinetic study of melamine in the presence and absence of cyanuric acid in rats. J Appl Toxicol, 33, 444-450.

23. Partanen H, Vahakangas K, Woo CS, et al (2012): Transplacental transfer of melamine. Placenta, 33, 60-66.

24. Puschner B, Reimschuessel R (2011): Toxicosis caused by melamine and cyanuric acid in dogs and cats: uncovering the mystery and subsequent global implications. Clin Lab Med, 31, 181-199.

25. Radko L, Minta M, Stypula-Trębas S, et al (2010): Determination of melamine cytotoxicity. Bull Vet Inst Pulawy, 54, 223-228.

26. Reimschuessel R, Gieseker CM, Miller RA et al (2008): Evaluation of the renal effects of experimental feeding of melamine and cyanuric acid to fish and pigs. Am J Vet Res, 69, 1217-1228.

27. Srivastava GK, Alonso-Alonso ML, Fernandez-Bueno I, et al (2018): Comparison between direct contact and extract exposure methods for PFO cytotoxicity evaluation. Sci Rep, 8, 1425.

28. Stine CB, Reimschuessel R, Keltner Z, et al (2014): Reproductive toxicity in rats with crystal nephropathy following high doses of oral melamine or cyanuric acid. Food Chem Toxicol, 68, 142-153.

29. Sun F, Ma W, Xu L, et al (2010): Analytical methods and recent developments in the detection of melamine. Trends Anal Chem, 11, 1239-1249.

30. Sun H, Wang K, Wei H, et al (2016): Cytotoxicity, organ distribution and morphological effects of melamine and cyanuric acid in rats. Toxicol Mech Methods, 26, 501-510.
31. Tutun, H (2019): Anti-Proliferative Effect of Melamine on Human Colon Adenocarcinoma Cells. Kocatepe Vet Derg, 12, 264-267.

32. Ulukaya E, Acilan C, Ari F, et al (2011): A Glance at the methods for detection of apoptosis qualitatively and quantitatively. Turk J Biochem, 36, 261-269.

33. World Health Organization (2008): Melamine and cyanuric acid: toxicity, preliminary risk assessment and guidance on levels in food. Available at http://www.who.int/entity/foodsafety/fsmanagement/Mela mine.pdf. (Accessed December 02, 2019).

34. Wu HN, Li HY, Chua FZH, et al (2013): Rapid detection of melamine based on immunoassay using portable surface plasmon resonance biosensor. Sensor Actuat B-Chem, 178, 541-547.

35. Xie Z, Yuan H, Chen Q, et al (2011): Study on compound of melamine and cyanuric acid on liver damage in mice. Chin J Vet Sci, 31, 1348-1353.

36. Yin RH, Wang X, Wang XZ, et al (2013): Effect of melamine in the absence and presence of cyanuric acid on ultrastructure of visceral organs in male mice. Isr J Vet Med, 68, 56-64.

37. Yin RH, Liu J, Li HS, et al (2014): The toxic effects of melamine on spleen lymphocytes with or without cyanuric acid in mice. Res Vet Sci, 97, 505-513.

38. Yin RH, Li XT, Wang X, et al (2016): The effects of melamine on humoral immunity with or without cyanuric acid in mice. Res Vet Sci, 105, 65-73.

39. Yin RH, Dong Q, Li HS, et al (2017): The effects of melamine with or without cyanuric acid on immune function in ovalbumin-sensitized mice. Res Vet Sci, 114, 254-261.

40. Yin RH, Huang C, Yuan J, Li W, et al (2019): $i T R A Q$ based proteomics analysis reveals the deregulated proteins related to liver toxicity induced by melamine with or without cyanuric acid in mice. Ecotoxicol Environ Saf, 174, 618629.

41. Yiu AJ, Ibeh CL, Roy SK, et al (2017): Melamine induces Ca2+-sensing receptor activation and elicits apoptosis in proximal tubular cells. Am J Physiol Cell Physiol, 313, C27-C41.

42. Yoon YS, Kim DH, Kim SK, et al (2011): The melamine excretion effect of the electrolyzed reduced water in melamine-fed mice. Food Chem Toxicol, 49, 1814-1819.

43. Zhang QX, Yang GY, Li WX, et al (2011): Melamine induces sperm DNA damage and abnormality, but not genetic toxicity. Regul Toxicol Pharmacol, 60, 144-150. 